\title{
Characterization of artificially induced zinc-tolerant yeast mutants
}

\author{
Sangman Lee ${ }^{1}$ \\ 아연 저항성 갖는 인위적으로 유도된 효모 돌연변이체의 특성 \\ 이상만 ${ }^{1}$
}

Received: 10 January 2017 / Accepted: 7 March 2017 / Published Online: 30 June 2017

(C) The Korean Society for Applied Biological Chemistry 2017

\begin{abstract}
Bioremediation is a technique using microorganisms to clean up contaminated pollutants including heavy metals. It is well known that yeasts have a high capacity to remove a wide range of metals by biosorption. Therefore, this study was focused on to obtain yeast mutant that has strong tolerance to zinc $(\mathrm{Zn})$, one of representative heavy metals. The $\mathrm{Zn}$ resistant yeast mutant $(\mathrm{ZnR})$ was induced and isolated by growing yeast cells in media containing $1 \mathrm{mM} \mathrm{ZnCl}$ and gradually increasing the concentration until $80 \mathrm{mM} \mathrm{ZnCl}$, in which cells were adapted and survived. The induced $\mathrm{ZnR}$ cells showed strong tolerance to $\mathrm{Zn}$ stress compared with control cells. Moreover, the $\mathrm{ZnR}$ cells showed increased tolerance to cadmium and nickel stress but decreased tolerance to copper stress. The increased tolerance of $\mathrm{ZnR}$ cells to $\mathrm{Zn}$ stress was due to mutation of genes. This study can be useful in bioremediation of heavy metals as the metal tolerant microorganism was artificially induced in short time.
\end{abstract}

Keywords Bioremediation - Heavy metal $\cdot$ Mutation · Yeast · Zinc

Sangman Lee $(\square)$

E-mail: sangman@knu.ac.kr

${ }^{1}$ Division of Applied Biology and Chemistry, School of Applied Biosciences, College of Agriculture and Life Sciences, Kyungpook National University, Daegu 702-701, Republic of Korea

This is an Open Access article distributed under the terms of the Creative Commons Attribution Non-Commercial License (http://creativecommons. org/licenses/by-nc/3.0/) which permits unrestricted non-commercial use, distribution, and reproduction in any medium, provided the original work is properly cited.

\section{서 론}

중금속은 생물의 성장에 불필요한 카드뮴, 납, 수은 등이 존재 하며 이들은 적은 양으로 존재해도 생물에 치명적으로 작용할 수 있으며 구리, 아연, 철 등의 생물의 성장에 필요한 중금속은 적정량 이상으로 존재할 때 생물에게 해를 끼친다. 따라서 생 물은 중금속 스트레스에 방어하는 메커니즘이 오랜 세월을 통 해서 발전되어 왔으며 현재도 진행 중이다.

중금속으로 오염된 수질 및 토양을 정화하기 위해서 미생물 이 이용되는 생물학적정화가 있다 $(\mathrm{Gad}$ 등, 2010 ; Gaur 등, 2014). Saccharomyces cerevisiae를 포함한 효모는 다양한 종류 의 금속을 흡착하고 세포들이 서로 쉽게 뭉쳐서 무게의 증가로 수질 환경에서 바닥으로 침전되는 방식으로 금속 제거하는 능 력이 탁월하다. 효모의 이러한 특징 때문에 중금속을 정화하는 생물학적정화에 효과적으로 이용이 된다(Soares와 Soares 2012). 하지만 중금속을 많이 축적하고 동시에 저항성도 높은 돌연변 이 된 효모를 분리하기란 불가능에 가깝다고 알려졌다(Ruta 등, 2010). 따라서 생물학적정화에 사용되는 미생물은 세포 내 중금 속 축적을 높이는 것에 초점을 두기 보다는 고농도의 중금속이 함유된 환경에서 죽지 않고 살아 남는 미생물 분리가 최근의 연구 동향이다(Soares와 Soares 2012; Gaur 등, 2014).

본 연구의 목적은 대표적인 중금속 중 하나인 아연에 큰 저 항성 갖는 효모의 분리가 인위적으로 실험실 조건에서 가능한 지를 알아보며 분리된 효모의 특성을 분석하며 또한 아연 저항 성과 관련성이 있는 후보 유전자를 알아보는 것이다.

\section{재료 및 방법}

\section{실험재료}

실험에 사용된 대조구 효모는 Saccharomyces cerevisiae strain INVsc1 (his341/his31 leu2/leu2 trp1-289/trp1-289 ura3-52/ura3- 
52) (Invitrogen, Carlsbad, CA, USA)로서 pYES2 벡터 (Invitrogen)를 포함하고 있으며 아연 저항성 효모 유도 및 분리 에 이용되었다. 효모 성장에 사용된 배지 $(\mathrm{SC}-\mathrm{Ura}+\mathrm{Glc})$ 는 우라 실이 없고 그 외 성장에 필요한 질소와 아미노산을 포함하고 있으며 $2 \%$ 포도당을 첨가하였다(Lee와 Kang 2005).

\section{아연 저항성을 갖는 효모 유도}

아연에 저항성을 갖는 효모 유도는 대조구 효모를 $5 \mathrm{~mL}$ 액체 배지에 접종해서 $30{ }^{\circ} \mathrm{C}$ 에서 $24 \mathrm{~h}$ 키운 후 자란 효모 $100 \mu \mathrm{L}$ 를 $1 \mathrm{mM} \mathrm{ZnCl}$ 이 포함된 $5 \mathrm{~mL}$ 배지에 접종하였다. $24-48 \mathrm{~h}$ 이내 에 효모가 잘 자라면 아연의 농도를 $1 \mathrm{mM}$ 단위로 점차 높였 으며 잘 자라지 않으면 아연의 농도를 높이지 않고 현재 또는 이전 사용된 농도에서 성장이 계속 진행되도록 하여 최종 80 $\mathrm{mM}$ 까지 하였으며 이 농도는 효모가 성장하는 한계점 근처의 농도로 보여진다. 이렇게 하여 아연에 저항성을 갖는 효모를 Zinc Resistant $(\mathrm{ZnR})$ 이라 명명하였으며 유도하는데 걸리는 시 간은 대략 6 개월 정도이다.

\section{금속 민감성 분석}

다양한 금속에 대한 효모의 민감성 분석은 액체배지에 $24 \mathrm{~h}$ 키 운 효모 $50 \mu \mathrm{L}$ 를 다양한 금속이 여러 농도로 존재하는 $5 \mathrm{~mL}$ 액체배지에 접종하여 $30^{\circ} \mathrm{C}$ 에서 $24 \mathrm{~h}$ 키운 후 분광광도계로 600 $\mathrm{nm}$ 에서 흡광도를 측정하였다.

\section{DNA microarray 분석}

대조구와 $\mathrm{ZnR}$ 효모를 액체배지에 $30^{\circ} \mathrm{C}$ 에서 $24 \mathrm{~h}$ 키운 후 RNA를 추출한 후 Agilent's 2100 Bioanalyzer System (Agilent Techonlogies, Palo Alto, CA, USA)을 이용하여 전체 RNA의 질을 측정하였고 Agilent's Low RNA Input Linear Amplification kit PLUS를 이용하여 증폭 및 라벨링 과정을 거쳤으며 microarray hybridization/wash은 Agilent's Gene Expression Hybridization/Wash Kit를 이용하였다. 사용된 microarray는 Agilent사의 Agilent yeast whole genome (V1) $4 \times 44 \mathrm{~K}$ array 이다. 스캔 및 영상분석은 Agilent's DNA microarray scanner 및 Feature Extraction Software를 이용하였고 데이터 분석은 Agilent's GeneSpring Software를 이용하여 normalization 및 clustering 등을 수행하였다.

\section{결과 및 고찰}

\section{$\mathrm{ZnR}$ 의 아연 저항성 분석}

오랜 기간 동안 중금속에 노출된 미생물은 그렇지 않은 미생물 에 비해서 중금속저항성이 높다는 연구 결과가 있다(Díaz-Raviña 와 Bååth 2001; Villegas 등, 2005; Zafar 등, 2007). 또한 미 생물을 중금속 스트레스에 인위적으로 오랜 기간 노출시켜 중 금속에 대한 저항성 증가를 유도할 수 있다는 연구 결과도 있 다(Díaz-Raviña와 Bååth 1996). 본 연구에서 인위적으로 효모를 지속적으로 아연에 노출시켜 아연에 대한 저항성이 증가된 효 모 $\mathrm{ZnR}$ 은 성장 속도, 콜로니 모양 및 색깔에 있어 대조구인 효 모와 비교하여 차이가 없었다. 분리된 $\mathrm{ZnR}$ 이 아연에 대한 저 항성 증가가 일시적인 아연 스트레스에 대한 적응인지 아니면

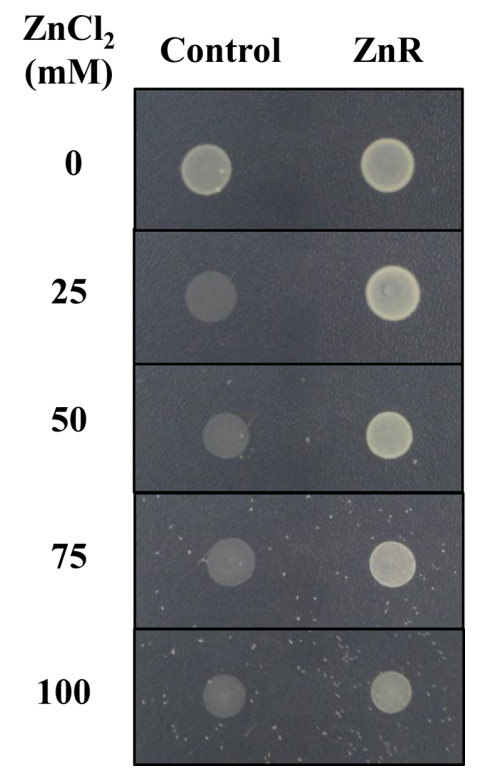

Fig. 1 Comparison of sensitivity to $\mathrm{Zn}$ of control and $\mathrm{Zn}$ resistant $(\mathrm{ZnR})$ yeast mutant. Both control and $\mathrm{ZnR}$ cells were grown on SC-Ura+Glc agar media containing various concentrations of $\mathrm{Zn}$ for $48 \mathrm{~h}$ at $30^{\circ} \mathrm{C}$, after which photographs were taken

영구적으로 획득한 것인지를 알아보기 위해서 $\mathrm{ZnR}$ 을 아연 스 트레스가 없는 배지에 여러 번 성장하게 해서 아연에 대한 일 시적 적응을 없앴다. 이러한 $\mathrm{ZnR}$ 을 다양한 농도의 아연이 포 함된 고체배지에 $10 \mu \mathrm{L}$ 접종한 후 $2 \mathrm{~d}$ 배양하여 아연에 대한 저항성 증가가 영구적인지 분석하였다(Fig. 1). 대조구 효모는 아연의 농도가 $25 \mathrm{mM}$ 일 때 콜로니 생성이 안되었지만 $\mathrm{ZnR}$ 은 아연의 농도가 $100 \mathrm{mM}$ 인 경우에도 콜로니 생성이 가능하였다. 이러한 결과는 $\mathrm{ZnR}$ 이 고농도의 아연에 대한 저항성 증가가 일 시적인 적응에 의한 것이 아니고 영구적으로 획득한 것이며 그 이유로서 아연 저항성 관련 유전자에 돌연변이가 일어난 결과 라고 추정된다.

\section{$\mathrm{ZnR}$ 의 다양한 금속 저항성 분석}

한 종류의 중금속 스트레스에 적응된 미생물은 종종 다른 종류 의 중금속에 저항성을 보이기도 한다(Rehman 등, 2008). 따라 서 $\mathrm{ZnR}$ 이 아연뿐만 아니라 다른 종류의 금속 스트레스에도 저 항성을 획득했는지를 알아보았다(Fig. 2). 이번에는 고체배지가 아닌 액체배지 조건에서 아연에 대한 저항성을 비교한 결과 대 조구 효모는 아연의 농도가 $20 \mathrm{mM}$ 일 때 성장이 거의 일어나 지 않았으며 $30 \mathrm{mM}$ 일 때는 성장이 멈쳤고 이에 반해서 $\mathrm{ZnR}$ 은 아연의 농도가 $60 \mathrm{mM}$ 되어도 성장은 $40 \%$ 정도만 억제 되었 지만 성장은 지속적으로 유지됨을 알 수 있다(Fig. 2A). ZnR은 아연뿐만 아니라 카드뮴에 대한 저항성도 증가되었음을 볼 수 있었고(Fig. 2B) 니켈에 대한 저항성 증가도 있음을 알 수 있 었다(Fig. $2 \mathrm{C}$ ). $\mathrm{ZnR}$ 은 구리에 대한 저항성은 오히려 감소되었 고(Fig. 2D) 알루미늄과 수은에 대한 저항성은 변화가 없음을 확인하였다(Fig. 2E, F), 본 연구에서 효모의 아연에 대한 저항 성 증가가 아연 이외의 다른 금속인 카드뮴과 니켈에 대한 저 항성 증가로 이어질 수 있는 것은 기존의 연구 결과와 유사하 

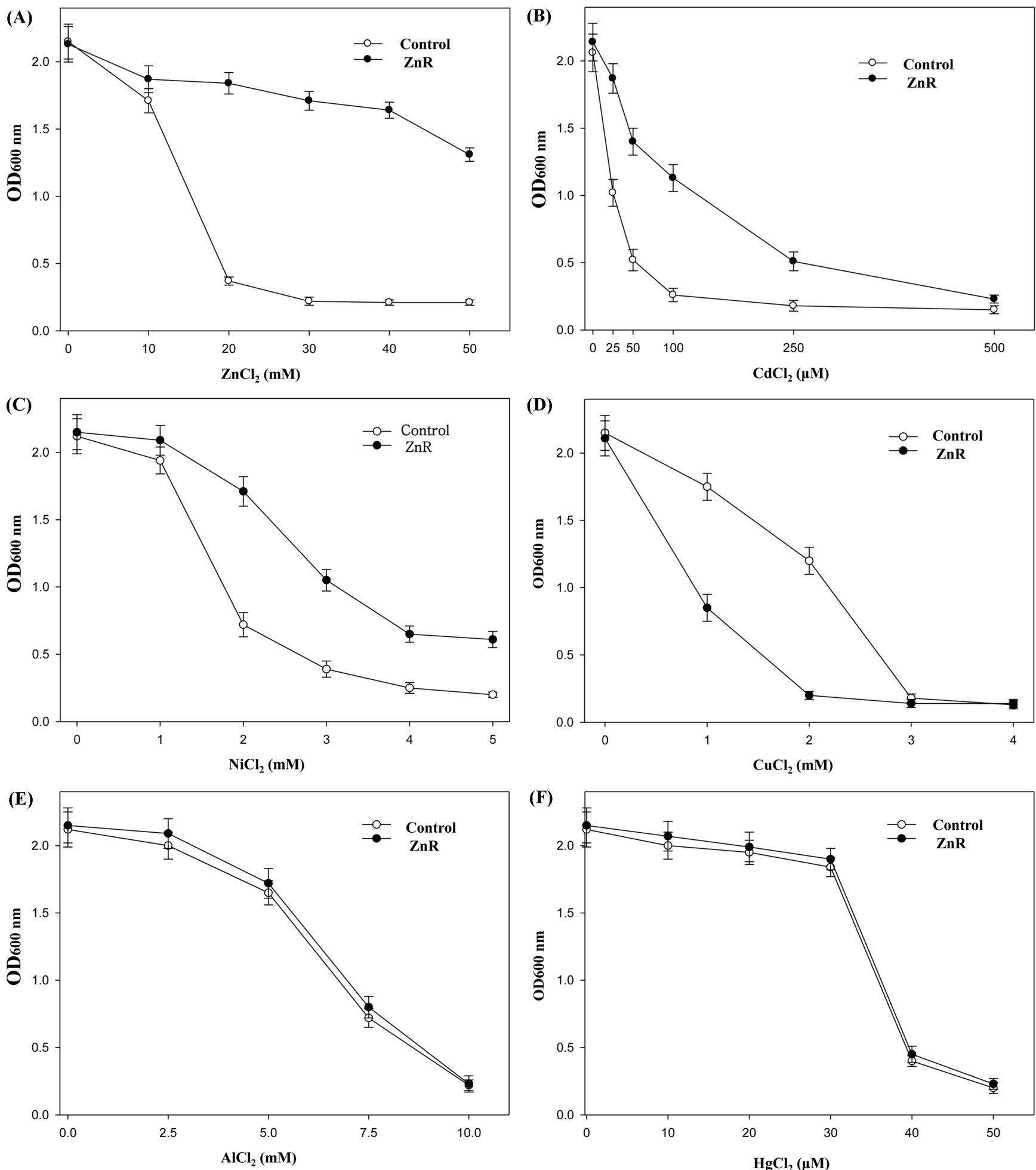

Fig. 2 Comparison of sensitivity to various metals between control and $\mathrm{Zn}$ resistant $(\mathrm{ZnR})$ yeast mutant. Both control and $\mathrm{ZnR}$ cells were grown in liquid SC-Ura+Glc media containing various concentrations of metals for $24 \mathrm{~h}$ at $30^{\circ} \mathrm{C}$. (A), $\mathrm{Zn}$; (B), Cd; (C), Ni; (D), Cu; (E), Al; (F), Hg. Cell density was then measured spectrophotometrically at $600 \mathrm{~nm}$. Values shown are the means $\pm \mathrm{SE}$ of three replicates 
Table 1 Partial list of up-regulated genes in $\mathrm{Zn}$ resistant $(\mathrm{ZnR})$ yeast mutant

\begin{tabular}{cll}
\hline Fold change & Gene symbol & \multicolumn{1}{c}{ Molecular function } \\
\hline 90.73 & MF(ALPHA)1 & pheromone \\
65.12 & ORF:YLR012C & molecular_function unknown \\
55.94 & SAG1 & cell adhesion receptor \\
42.26 & AGA1 & cell adhesion receptor \\
29.87 & ORF:YGL193C & molecular_function unknown \\
28.82 & URA3 & orotidine-5-phosphate decarboxylase \\
25.09 & YGP1 & molecular_function unknown \\
20.30 & RME1 & transcription factor \\
20.02 & SCS7 & not yet annotated \\
19.75 & STE3 & mating-type a-factor pheromone receptor \\
19.42 & PGM2 & phosphoglucomutase \\
17.43 & UBC4 & ubiquitin conjugating enzyme \\
17.10 & FRE7 & molecular_function unknown \\
16.87 & PRM1 & molecular_function unknown \\
16.80 & SPI1 & molecular_function unknown \\
15.47 & ORF:YML025C & structural constituent of ribosome \\
13.33 & ROX3 & RNA polymerase II transcription mediator \\
13.09 & SRC1 & molecular_function unknown \\
12.93 & FPR3 & peptidyl-prolyl cis-trans isomerase \\
12.42 & REG2 & protein phosphatase type 1 \\
12.20 & FUS3 & MAP kinase \\
11.94 & MET10 & sulfite reductase (NADPH) \\
11.70 & SSY5 & molecular_function unknown \\
11.58 & ORF:YGR067C & molecular_function unknown \\
11.47 & ORF:YDR116C & structural constituent of ribosome \\
11.21 & ORF:YCR041W & molecular_function unknown \\
11.11 & PRC1 & carboxypeptidase C \\
10.62 & DCP2 & molecular_function unknown \\
10.59 & PMT1 & dolichyl-phosphate-mannose-protein \\
10.56 & TPO3 & mannosyltransferase \\
\hline & & spermine transporter \\
\hline
\end{tabular}

지만(Ahemad와 Malik 2012) 구리에 대한 저항성 감소는 일련 의 아연 저항성 유도 과정에서 구리 저항성 관련 유전자에 돌 연변이가 일어난 결과라고 추정된다.

\section{$\mathrm{ZnR}$ 의 변화된 유전자 발현 분석}

카드뮴, 납, 아연 등을 포함한 대부분의 중금속은 돌연변이를 유발하는 물질로 알려져 있다(Jin 등, 2003; Giaginis 등, 2006) 미생물은 중금속 스트레스에 적응하기 위해서 생리적 및 유전 적 적응을 통해서 이루어진다(Duxbury와 Bicknell 1983; DíazRaviña와 Bååth 1996). 따라서 $\mathrm{ZnR}$ 이 아연에 대한 저항성 증 가의 원인으로 관련 유전자의 돌연변이에 기인한다고 추정되며 이를 확인하기 위해서 DNA microarray 분석을 하였다. 그 결 과 $\mathrm{ZnR}$ 은 control 효모와 비교하여 10 배 이상 유전자발현이 증 가된 것이 30 유전자 이상이며(Table 1) 정 반대로 유전자발현 이 5 배 이상 감소한 것도 30 유전자 정도로 보였다(Table 2). 발현이 증감된 상당수의 유전자의 기능은 아직 잘 알려지지 않 았으며 아마도 아연 중금속 저항성에 관련이 있다고 추정된다.
Table 2 Partial list of down-regulated genes in $\mathrm{Zn}$ resistant $(\mathrm{ZnR})$ yeast mutant

\begin{tabular}{cll}
\hline Fold change & Gene symbol & \multicolumn{1}{c}{ Molecular function } \\
\hline 0.05 & SPS100 & molecular_function unknown \\
0.07 & ORF:YKR105C & not yet annotated \\
0.08 & ORF:YOR055W & molecular_function unknown \\
0.08 & ORF:YGL007W & molecular_function unknown \\
0.08 & SOL2 & molecular_function unknown \\
0.09 & ORF:YFL067W & molecular_function unknown \\
0.09 & GIT1 & molecular_function unknown \\
0.10 & ORF:YCR105W & molecular_function unknown \\
0.10 & ORF:YCR013C & molecular_function unknown \\
0.11 & ORF:YCR100C & molecular_function unknown \\
0.12 & ORF:YDL222C & molecular_function unknown \\
0.13 & ORF:YLR279W & molecular_function unknown \\
0.13 & JIP4 & molecular_function unknown \\
0.14 & ORF:YAL018C & molecular_function unknown \\
0.14 & PGK1 & phosphoglycerate kinase \\
0.14 & ORF:YDL152W & molecular_function unknown \\
0.14 & ORF:YBL100C & molecular_function unknown \\
0.15 & BAP2 & amino acid transporter \\
0.15 & ECM23 & molecular_function unknown \\
0.15 & ORF:YOR338W & molecular_function unknown \\
0.15 & ORF:YCR099C & molecular_function unknown \\
0.15 & ORF:YHR214W & molecular_function unknown \\
0.15 & ORF:YAR066W & molecular_function unknown \\
0.16 & ORF:YOR263C & molecular_function unknown \\
0.16 & ORF:YKL102C & molecular_function unknown \\
0.16 & SPC25 & structural constituent of cytoskeleton \\
0.16 & AQY2 & water channel \\
0.17 & MAM1 & molecular_function unknown \\
0.17 & PB12 & endopeptidase inhibitor \\
0.17 & ORF:YKR005C & molecular_function unknown \\
0.17 & TIR3 & molecular_function unknown \\
0.17 & ORF:YCL069W & not yet annotated \\
\hline & &
\end{tabular}

유전자 기능이 알려진 것 중에서 sulfite reductase는 시스테인 생합성에 관여하며 대조구와 비교해서 발현이 12 배 증가하였 다. 시스테인은 중금속 스트레스 방어에 중요한 역할을 하는 클 루타치온(glutathione)과 메탈로티오닌(metallothionein)의 주요구 성성분의 아미노산이다(Yadav 2010; Sakulsak 2012). 본 연구에 서 분리된 $\mathrm{ZnR}$ 이 아연에 대해서 저항성이 증가된 이유는 세포 내로 들어온 과량의 아연을 글루타치온과 메탈로티오닌에 존재 하는 시스테인의 $\mathrm{SH}$ 기가 아연과 결합하여 아연의 독성을 줄여 주기 때문이라고 추정된다. 이번 실험의 결과는 $\mathrm{ZnR}$ 이 아연 저 항성 관련 유전자에 돌연변이가 일어나 아연에 대한 저항성 증 가가 영구적 획득된 것임을 알려준다.

본 연구 결과는 효모의 아연에 대한 저항성 증가는 돌연변이 에 의한 영구적 획득으로서 실험실 조건 내에서 인위적으로 유 도 가능하며 중금속을 정화하는 생물학적정화에 유용하게 될 것 임을 확인시켜준다. 


\section{초 록}

생물학적정화는 미생물을 이용하여 중금속을 포함한 오염물질 을 정화하는 방법이다. 효모는 다양한 중금속을 흡착하여 정화 하는 능력이 우수하다고 잘 알려졌다. 따라서 본 연구는 여러 중금속 중 하나인 아연에 저항성인 큰 효모를 인위적인 돌연변 이를 통해서 얻는 것에 초점을 두었다. 대조구인 효모를 $1 \mathrm{mM}$ 농도의 아연이 포함된 배지에서 키운 후 점차 아연의 농도를 높여 최종적으로 $80 \mathrm{mM}$ 이 되는 지점까지 키웠으며 이 농도는 효모가 점진적 적응을 거쳤어도 성장이 불가능한 한계점 근처 이며 이렇게 유도 분리된 효모를 $\mathrm{ZnR}$ 이라 명명하였다. $\mathrm{ZnR}$ 은 대조구 효모보다 아연에 대한 저항성이 현저히 증가되었으며 이 외에 카드뮴과 니켈에 대한 저항성도 증가되었지만 구리에 대 한 저항성은 오히려 감소 되었다. $\mathrm{ZnR}$ 이 보여준 아연에 대한 저항성 증가는 유전자 돌연변이에 의한 영구적인 획득 결과이 다. 단 기간 내에 아연에 대한 저항성 큰 효모의 인위적인 유 도 및 분리는 생물학적정화 연구에 유용하게 쓰여질 정보이다.

Keywords 돌연변이 · 생물학적정화 · 아연 · 중금속 · 효모

\section{References}

Ahemad M, Malik A (2012) Bioaccumulation of heavy metals by zinc resistant bacterial isolated from agricultural soils irrigated with wastewater. Bacteriol J 2: 12-21

Díaz-Raviña, Bååth E (1996) Development of metal tolerance in soil bacterial communities exposed to experimentally increased metal levels. Appl Environ Microbiol 62: 2970-2977

Díaz-Raviña M, Bååth E (2001) Response of bacterial communities preexposed to different metals and reinoculated in an unpolluted soil. Soil
Biology Biochemistry 33: 241-248

Duxbury T, Bicknell B (1983) Metal-tolerant bacterial populations from natural and metal-polluted soils. Soil Biol Biochem 15: 243-250

Gad AS, Attia M, Ahmed HA (2010) Heavy metals bio-remediation by immobilized Saccharomyces cerevisiae and Opuntia indica waste. J American Sci 6: 79-87

Gaur N, Flora G, Yadav M, Tiwari A (2014) A review with recent advancements on bioremediation-based abolition of heavy metals. Environ Sci Proceses Impacts 16: 180-193

Giaginis C, Gatzidou E, Theocharis S (2006) DNA repair systems at targets of cadmium toxicity. Toxicol Appl Pharmacol 213: 282-290

Jin YH, Clark AB, Slebos RJ, Al-Rafai H, Taylor JA, Kundel TA, Resnick MA, Gordenin DA (2003) Cadmium is a mutagen that acts by inhibiting mismatch repair. Nat Gen 34: 326-329

Lee S, Kang BS (2005) Phytochelatin is not a primary factor in determining copper tolerance. J Plant Biol 48: 32-38

Rehman A, Farooq H, Hasnain S (2008) Biosorption of copper by yeast, Loddermyces elongisporus, isolated from industrial effluents: its potential use in wastewater treatment. J Basic Microbiol 48: 195-201

Ruta L, Paraschivescu C, Matache M, Avramescu S, Farcassanu IC (2010) Removing heavy metals from synthetic effluents using "kamikaze" Saccharomyces cerevisiae cells. App Microbiol Biotechnol 85: 763-771

Sakulsak N (2012) Metallothionein: An overview on its metal homeostatic regulation in mammals. Int J Morphol 30: 1007-1012

Soares EV, Soares HM (2012) Bioremediation of industrial effluents containing heavy metals using brewing cells of Saccharomyces cerevisiae as a green technology: a review. Environ Sci Pollut Res Int 19: 1066-1083

Villegas LB, Amoroso MJ, deFigueroa LIC (2005) Copper tolerant yeasts isolated from polluted area of Argentina. J Basic Microbiol 45: 381-391

Yadav SK (2010) Heavy metals toxicity in plants: An overview on the role of glutathione and phytochelatins in heavy metals stress tolerance of plants. South African J Bot 76:167-179

Zafar S, Aquil F, Ahmad I (2007) Metal tolerance and biosorption potential of filamentous fungi isolated from metal contaminated agricultural soil. Bioresource Technology 98: 2557-2561 